\title{
A REVIEW OF CRITICS AGAINST THE CALL FOR INDIGENOUS SOCIOLOGY IN TURKEY
}

\author{
Fahri ÇAKI*
}

\begin{abstract}
The call for indigenous sociology is a discussion that reflects reactions to the Eurocentric character of Western sociology and alternative proposals. According to the advocates of this call, Western sociology, based on the social and historical experiences of Western societies, do not allow understanding non-Western societies that have different backgrounds from the West, and that it is also against their interests. It also creates intellectual dependence and inequalities not only in the global production of knowledge, but also in its distribution, circulation and consumption. Therefore, non-Western societies are called upon to build an indigenous sociology. No matter how solid it may sound, this call has also been subject to various criticisms due to some of its limitations. This paper aims to analyze and evaluate the criticisms of the call, which ironically turned into a global call, in the context of Turkish Sociology. The paper argues that the criticisms of this call should be reconsidered within the framework of four main questions: 1) How successful have the followers of the call been in constructing a sociology appropriate to the requirements of the call? 2) Do today's national and global conditions still make this call meaningful and necessary? 3) How does this call affect the disciplinary integrity and scientific identity of sociology? 4) What could be the future of the call? The paper concludes that indigenous sociology is not a utopia.
\end{abstract}

Keywords: Eurocentrism, Indigenization, Epistemic Hegemony, Reconstruction of Sociology, Global Sociology, Indigenous Sociology.

\section{TÜRKIYE'DE YERLİ SOSYOLOJI ÇAĞRISINA KARŞIT ELEŞTİRILERE BAKIŞ ÖZ}

1970'lerde başlayıp günümüze kadar devam eden yerli sosyoloji çağrısı, Batı sosyolojisinin Avrupa merkezli karakterine epistemolojik ve ontolojik gerekçelerle gösterilen tepkileri ve alternatif önerileri içeren bir tartışmadır. $\mathrm{Bu}$ çağrının savunucularına göre, Batı toplumlarının sosyal ve tarihsel deneyimlerine dayanan sosyolojinin kuram, kavram ve yöntemleri, Batı'dan farklı sosyal, kültürel ve tarihsel deneyimlere sahip Batı-dışı toplumları anlamaya ve açıklamaya izin vermediği gibi onların çıkarlarına da aykıııdır. Ayrıca bilginin yalnızca küresel üretiminde değil, dağıtımında, dolaşımında ve tüketiminde de entelektüel bir bağımlılık ve eşitsizlikler yaratmaktadır. $\mathrm{Bu}$ nedenle, Batılı olmayan toplumlardan kendi yerli sosyolojilerini inşa etmeleri çağrısı yapılmaktadır. Kulağa ne kadar sağlam gelse de bazı sınırlılıklarından dolayı bu çağrı da çeşitli eleştirilere konu olmaktadır. Bu makale, ironik bir şekilde küresel bir çağrıya dönüşen yerli sosyoloji çağrısına yönelik eleştirileri Türk Sosyolojisi bağlamında analiz etmeyi ve değerlendirmeyi amaçlamaktadır. Makale, bu çağrıya yönelik eleştirilerin dört ana soru çerçevesinde yeniden ele alınabileceğini ileri sürmektedir: 1) Çağrının takipçileri çağrının gereklerine uygun bir sosyoloji inşa etmede ne kadar başarılı olmuştur? 2) Günümüzün ulusal ve küresel koşulları, bu çağrıyı hala anlamlı ve gerekli kılmakta mıdır? 3) Bu çağrı sosyolojinin disiplin bütünlüğünü ve bilimsel kimliğini nasıl etkiler? 4) Çağrının geleceği ne olabilir? Makale, yerli sosyolojinin bir ütopya olmadığı sonucuna varır.

Anahtar Kelimeler: Avrupamerkezcilik, Yerlileşme, Epistemolojik Hegemonya, Sosyolojinin Yeniden İnşası, Küresel Sosyoloji, Yerli Sosyoloji.

Atıf: ÇAKI, F. (2021)., “Türkiye'de Yerli Sosyoloji Çağrısına Karşıt Eleştirilere Bakış”, IMGGELEM, 5 (9): 155186.

Citation: ÇAKI, F. (2021). "A Review of Critics Against The Call For Indigenous Sociology in Turkey" İMGELEM, 5 (9): 155-186.

Başvuru / Received: 22 Ağustos /August 2021.

Kabul / Accepted: 17 Eylül / September 2021.

Derleme Makale/ Review Article.

\footnotetext{
* Prof. Dr., Balıkesir University, Department of Sociology, E-mail: cakifahri@ balikesir.edu.tr, ORCID Number: 0000-0002-8895-229
} 


\section{INTRODUCTION}

Sociology, like other sciences, progresses cumulatively. Theories and concepts produced in this accumulation process are constantly discussed, criticized and reconstructed. This process gives sociologists an opportunity to review their intellectual positions. Neither staying fixed on a certain idea nor immediately giving up one's intellectual position in the face of any criticism are a virtue in itself. Criticisms create opportunities for the sociologist to put his/her position on a more solid foundation. At the same time, changing/transforming social and historical realities may require reconsideration of thoughts. The sociologist's use of these opportunities, following new developments in the literature, and re-questioning his/her position at regular intervals does not make him weak, on the contrary, it strengthens him. Based on this proposition, I write this article to review my own thoughts and those of some others on the theme of calling for indigenous sociology.

The call for indigenous sociology is simply a reaction to Western sociology. Since it usually originates from South/Eastern countries, this call can be given names such as "Theory of the South", "epistemologies of the South", "alternative discourses", and, ironically, it is also considered as a derivative of "global sociology" projects (Go 2016: 2). Although it is a movement with various differences in itself, it can be said that it is united around the critique of the narrow-minded "Northern" or "Eurocentric" character of traditional sociology and the desire to transcend it. Turkish sociologists have widely recognized this reaction with Baykan Sezer $(1985,1988,1993)$ and identified with him. However, it is understood that more or less the same or similar calls were made in many parts of the world, especially during the 1970s and 1980s.

There is an almost implicit race going on for the initiators of indigenous sociology debates. For example, the starting point of the call for indigenous sociology is often initiated in international literature by the name of the Nigerian sociologist Akinsola Akiwowo. Although his call elicited mixed reactions, it is considered one of the first attempts to criticize the problematic position of non-Western sociologies in the 1980s and to encourage a more selfconfident approach. Akiwowo's $(1986,1988)$ project of indigenization was based on "a call for learning from the traditions of various cultures in order to develop, through a process of investigation and argumentation, universal propositions and frameworks that would be adequate for the task in a variety of locations" (Bhambra 2013: 303). On the other hand, Indian writers try to start this process with the Lucknow School of Economics and Sociology, founded 
in the 1920's under the leadership of Radhakamal Mukerjee and D. P. Mukerji. According to them, the names mentioned criticized the use of colonial approaches and concepts to understand social and political problems in India and instead advocated the development of an alternative approach or model that corresponds to Asian conditions and traditions (Joshi 1986, cited by Bhambra 2014: 87-88). In Turkey, it is known that Baykan Sezer made such a call for indigenous sociology in the 1980s. It doesn't really matter who started the process first. It is highly probable that many authors, both mentioned and not mentioned here, who call for an indigenous sociology, have developed common discourses, perhaps unaware of each other, in the face of common problems experienced under the political, economic and epistemic hegemony of the West.

These discourses and discussions began to resonate at the institutional level too in the same period. As a matter of fact, the journals of the International Sociological Association (ISA) have published a series of articles on the subject since the 1980s (Akiwowo 1986, 1988, 1999; Adésínà 2002; Archer 1991; Arjomand 2000; S. F. Alatas 2001; S. F. Alatas 2003; S. H. Alatas 2006; Baber 2003; Gareau 1985; Genov 1991; Diawara 2000; Oommen 1991). The issue of indigenization was discussed in many national and international meetings held under different auspices. For example, in the 'Towards a Global Sociology' workshop organized by the International Sociological Association at Sydney University in July 2013, participants focused on topics such as centers and circles (or alternatively, the relationship between the global south and the global north) and the possibility of constructing a global sociology (Rahbari 2015: 156). The indigenization movement began to gain momentum in the early 1970 s, when indigenous scientists from the Third World spoke out against the establishment of the social sciences that perpetuated the "slavery" of the mind; tater on, a number of social scientists from Western countries who shared this concern joined them. Thus, calls for the indigenization, Koreanization, Chineseization, Indianization, Africanization and Islamization of sociology/social sciences spread rapidly all over the world. What is interesting is that it is not only non-Western countries that talk about the indigenization of social sciences; for example, even Canadian social scientists are making symposiums, reports and publications on the Canadianization of social sciences (Candela 2015: 369).

It is not surprising that indigenization, which has turned into a global call, has gained a variable and multiple characters in terms of the meanings and programs attributed to it. As a matter of fact, even the names attributed to it are a clear indication of this: counter-hegemonic sociology (Keim 2011), autonomous sociologies (Alatas 2006), global sociology (Go 2016; 
Bhambra 2013), international sociology (Genov 1991; Arjomand 2000), Southern Sociology, alternative sociologies, etc. The variable and multiple characters of the names, meanings and programs attributed to indigenization indicate that it is a much more complex intellectual enterprise than it seems. Therefore, dozens of publications continue to be made around the questions of what the indigenization of sociology/social sciences is, what it is not, what it should be and what kind of barriers exit in front of it. Within Turkish sociology, some sociologists such as Çakı (2003), Şan (2007), Şan and Şenkaloğlu (2019), Çav (2019), Kızılçelik (2015), Kayalı (2009) and Eğribel (2010) discussed these questions.

This article, instead of refocusing on the aforementioned questions, suffices to summarize the epistemological and ontological grounds of the call for the indigenization of sociology/social sciences, and as its main focus, it aims to examine what kind of critical reactions have been developed over time against this call and to discuss how to evaluate these reactions.

\section{Reasons Behind the Call for Indigenization}

Actually, there are many (justified) reasons for this reaction, which is not limited to sociology, but covers all social sciences and is mostly developed by social scientists of nonWestern societies. Şan (2007) argues that there are four main historical factors that influenced the emergence of alternative approaches to Western sociology: 1) The devastating consequences of the two world wars and their disappointments about modernity, 2) The Nietzsche effect and postmodernist thought (Foucault, Bauman, etc.), 3) Struggles for independence, 4) Cultural studies (Şan 2007: 68). Another classification of justifications, including this analysis of Şan, can be considered as epistemological and ontological reasons.

In this context, the point that is most emphasized in connection with both types of justification is that Western Sociology has a Euro/Western centered character (Çakı 2003; Şan 2007; Şan \& Şenkaloğlu 2019; Çav 2019; Fals-Borda \& Mora-Osejo 2003). Eurocentrism is the practice of emphasizing, consciously or otherwise, European (and generally Western) concerns, historical development, culture, and values at the expense of other societies. In other words, this practice, which is essentially an "ideological distortion" (Amin 2009), gives an exceptional position to Europe (the West in general) as the owner of a distinct culture that emphasizes its commitment to rationalism, progress and universality. It conceptualizes modernity as a peculiar phenomenon unique to Europe, belittles the history of other cultures. While analyzing the wealth of Europe, it emphasizes the cultural and ideological superiority of 
the continent rather than the material conditions that allowed the "European miracle" to occur, neglects the dark sides of European history as mere deviations, neglects the achievements of other cultures and underestimates their contributions (Wallerstein 1997; Xypolia 2016).

Eurocentrism, which constructs civilization through dichotomies, is not a phenomenon observed only in the works of the founders of sociology; it is also evident in the works of contemporary Western sociologists. For example, Giddens (1990: 1-3) states that modernity refers to the forms of social life or organization that emerged in Europe and that sociology is the study of this modern social life. Although this understanding makes the relationship between sociology and the 'other' (that is, not completely 'modern') problematic, this problem is tried to be overcome with another assumption: The assumption that the perspectives used to examine and evaluate Europe (the West or the North in general) can also be used to evaluate "nonWestern" societies.

Although there is a strong and insistent emphasis on the Western origin of modernity, it is expected that it has advanced to all continents transcending Europe; therefore it is assumed that social theory is "necessarily universal" (Patel 2010: 1).

The Eurocentric character of Western sociology underlies the epistemological objection of the call for indigenous sociology. Due to its/their nature, sociology/social sciences produces knowledge based on specific historical, social, cultural and political contexts, that is, based on local contexts. In this respect, social sciences are inherently local. First, they are local, in the context of the industrialization of Anglo-European societies, in the sense that social sciences were created and institutionalized to meet their specific needs (Wallerstein 1996: 23). They are also local in the sense that they were formulated to meet the specific needs and concerns of particular groups, such as the white male elite, in these societies. Indeed, sociology in Europe and North America during the nineteenth and twentieth centuries; centered around questions about issues such as race struggle, immigration, urbanization, industrialization, social movements and revolutions, all of which included the concerns of metropolitan elites (Connell 1997; Go 2016; Seidman 1991). In other words, specifically Western sociology was formed within the framework of the life experiences, problems and interests of the West. Despite this, knowledge based on local experiences has been generalized to the whole world, thus giving sociology an objective and universal identity. From this point of view, it can be said that Western sociology has actually created its own "native sociology". 
This situation creates the justification for non-Western societies, which have different experiences and problems and have different interests from the West, to establish their own indigenous sociology. Accordingly, Western sociology is epistemologically inadequate/invalid in understanding and explaining the social and historical realities of non-Western societies because the issues and problems that Western sociology focuses on and cares about do not concern non-Western societies closely and do not address their real problems. In addition, due to the fact that knowledge-power relations cannot be considered independently of each other, the demand to create a change in the international power relations in our favor requires that we produce knowledge ourselves with our own theories and methods in the field of social sciences (Çak1 2003: 96). In the words of Şan (2007: 80), “when talking about domestic or non-Western social science... there is a necessity of a social science perception that evaluates problems in terms of our own interests and our own history".

Euro/Western centrism also provides justification to indigenous sociology appeals for raising ontological objections too. This is an expression of intellectual dependence and inequality. Accordingly, the relationship between Western sociology and non-Western ${ }^{1}$ sociologies is a center-periphery relationship. In this relationship, non-Western (periphery) sociology is "an exogenous, subordinated and dependent sociology" (Keim 2011; Alatas 2001, 2003; Alatas 2006; Hountondji 1990). This means that Western (central) sociology determines the basic concepts, theories and methods, and the role of researchers working in peripheral sociologies consists of providing empirical data and materials to test these theories and, at best, to evaluate, confirm or reject them (Rahbari 2015: 160; see also Alatas 2003; Sinha 2000). Dependence on Western sociology destroys creativity and originality in non-Western societies and replaces it with imitation and adaptation; sociologists of non-Western societies do not develop any original theory and method (Çakı 2003: 96; Keim 2011: 124). As Rahbari puts it, "prevailing euro centrism in the social sciences and the academic imperialism of the Northern countries in relation to the South has been suggested to have contributed to create processes that produce and reproduce inequalities in the formulation and dissemination of knowledge, especially of social theory" (Rahbari 2015: 157).

This relationship of dependency is the main issue that Turkish sociologists, who attach importance to Baykan Sezer's call for indigenous sociology, complain the most. For example, with reference to Kayalı (2009), Çav (2019: 82) expresses the problem as follows: "Sociology

\footnotetext{
${ }^{1}$ Most writers use the terms North and South instead of West and non-Western.
} 
in Turkey is abstracted from its social realities and understood without establishing a connection with the world and developments in time. Social sciences in Turkey, and sociology in particular, is found to be in a dire situation' because of its 'submissive attitude in front of Western social science'. Our task must be focusing on solving those problems in parallel to our national interests and overcome this "submissive attitude"'. Based on such evaluations, it is often stated that Turkish sociology "is not able to form a system/theory attached to itself" and that it is reduced to be in a position of translator and transmitter (Köktürk 2011: 7; Çav 2019: 81; Sezer 1988: 8; Eğribel 2016).

Similar complaints are frequently observed in many other non-Western countries. For example, Rahbari (2015) criticizes Iranian sociology as follows: "Iranian sociological streams and trends are, as in some other eastern countries, deeply affected and dominated by western scholars' thoughts and theories, [...] seems to have very small contribution to the international literature of social science in terms of theorizing ability. What we call Iranian social science, more than a specific locally recognizable current, is the empirical body of literature produced to test imported theories inside the borders of a political entity named Iran." (Rahbari 2015: 156).

The intellectual dependency-oriented center-periphery relationship creates inequalities not only in the global production of knowledge, but also in its distribution, circulation and consumption (Patel 2010: 1). First of all, due to the predominant role of international publications in academic promotion, sociologists in non-Western societies tend to turn their backs on their local academic communities in accordance with the principle of "publish internationally or perish" and they are pushed to "publish according to the rules and preferences of a so called "international audience"” (Keim 2011:135). Institutional barriers put up by the information industry, its publishers and journals, and mainly by the epistemic communities of interconnected core countries perpetuate intellectual dependence (Patel 2010: 15). The greater accessibility of local/regional journals for non-Western sociologists who do not have the competence to publish in prestigious international sociology journals due to language and formation differences also renders their contributions largely invisible in the Northern and international sociology community. Examining the International Encyclopedia of Social Sciences (1968), that claims geographic representation in the selection of contributors, Gareau (1988) found out that only $0.9 \%$ of the authors in this encyclopedia were from Third World countries, a striking indicator of the intellectual inequalities in question. He also found out that only \% 0.3 of them came from Communist Eastern Europe while American-related authors 
made up \% 78.1 of the total (cited in Bhambra 2014: 88-89). Therefore, these conditions, which we have touched on with only a few dimensions, foster intellectual dependence "by receiving and applying concepts, theories and methodologies developed in the centre" (Keim 2011: 126).

These epistemological and ontological reasons make it necessary to restructure sociology (generally social sciences) in non-Western societies. So, what should be done for this? The answers to this question show a certain variety. According to Baykan Sezer, it is one of the main tasks of Turkish sociology to investigate how and in what way one can benefit from the richness of Turkish history, which covers a wide adventure from Central Asia to the NearEast and which can shed light on the present and future of Turkish society (Sezer 1985: 217). Therefore, Turkish sociologists, who are interested in the subject based on Sezer's thoughts, mostly emphasize the necessity of sociology to be based on history. That is because "history stands out as the only mirror of the formation of social interests" (Şan 2007: 77). Along with Turkish and world history, " it is also necessary to know the history of sociology in the West very well in order to construct the Indigenous Sociology," (Çav 2019: 104). In addition to these, in parallel with Akiwowo's $(1986,1988)$ "call to learn from indigenous traditions", Alver (2014) also points out the need to benefit from traditional sources. According to him, for indigenous sociology, it is necessary to refer to the indigenous/original literature and sources. For this, Turkish Sociology should develop its own literature (Alver 2014).

Malaysian sociologist Alatas (2006) summarizes in a broader context what is required for the construction of indigenous sociology: "Indigenization requires the turn to indigenous philosophies, epistemologies, histories, art and other modes of knowledge, which can all be potential sources of social science theories and concepts" (Alatas 2006: 86).

In this context, Adésínà (2006) argues that it is important and necessary to move from 'translation' to 'formulation'. This means not only an engagement with modern science, but also an attempt to radically reorganize the production, distribution and circulation of knowledge and liberate it from colonial imperatives (cited in Patel 2010: 9).

What would be the benefit of indigenizing sociology/social sciences? As can be understood from the explanations so far, indigenization, whose ultimate goal is "the creation of social sciences free from ethnocentrism and cultural dependency or ethnocentrism," can lead us "out of the monotonous and rigidly rationalized Western intellectual colors and flavor into a world of much more fun-ridden, colorful and scentful social sciences" (Dong 2017: 64). As a more important contribution, "indigenized social science theories and concepts should make 
much better sense, and hence be more meaningful, to the people of that particular society. [...] Indigenized social science can help develop more practically relevant policy ideas and recommendations for public action or other social movements, directly reflecting life experience the people" (Dong 2017: 64).

However, the call for indigenization takes different forms and emphasizes different aspects in different countries. In some countries that have recently introduced the social sciences, indigenization can only play the role of advocacy for the promotion and recognition of the social sciences and contributing to the nation-building process. In others, indigenization functions as an educational tool that serves the transition to the national language. Curriculum development with a bias towards national needs can also be considered as an indicator of indigenization for some countries.

In Turkey, the most important function of indigenous sociology, according to Sezer, is to shed light on the present and future of Turkish society, to highlight our interests against the interests of the West, and to reflect our view (Sezer 1985: 217; 1993: 21). According to Çav (2019), the most important function of indigenous sociology is to ensure that sociology, which has become a tool to legitimize westernization policies, establishes a peaceful relationship with its own society, history and culture: "With the concept of indigenous sociology' we mean an understanding of social science and sociology that that carries the historical, cultural, religious and intellectual accumulation of this geography such as Islam, Turkish, solidarity society, traditional family ties, reason and wisdom; such an understanding of social science and sociology does not ignore the structural codes that has successfully built a non-Western society and state system for centuries" (Çav 2019: 102).

The mentioned functions are the benefits that are desired for indigenous sociology to produce. The actual realization of this desire is another matter. As a matter of fact, Çak1 (2003) states that the benefits of indigenization of sociology/social sciences depend on which path it will take now and in the future. According to him, the call for indigenization may take two different paths: "First, it may take a path of legitimizing the demands and projects of the dominant powers within our own society. In such a path, based on a certain understanding of the state, it would take the direction of conceptualizing identities deemed worthy of society from above. On the other hand, as a second possibility, it may also take an anti-hegemonic path that serves the identities and interests of powerless social segments against global imperialism as well as internal dominant forces" (Çakı 2003: 111). 
In the light of the brief presentation above, it can be said that the call for indigenous sociology is based on justified reasons. However, in addition to the question of actual possibilities, this call may also carry potential epistemological problems arising from its challenging nature in terms of its basic aims and assumptions. Therefore, this call needs to be reconsidered in the framework of four main questions:

1) How successful/effective are the followers of the call for indigenous sociology in constructing a sociology that fits the requirements of the call?

2) To what extent do today's national and global conditions match those of the period (1980s) when the call for indigenous sociology was born? Does this harmony or incompatibility still make the call in question necessary and important?

3) How does the call for indigenous sociology affect the disciplinary integrity and scientific identity of sociology?

4) What future may the call for indigenous sociology have?

The remainder of the article will examine and evaluate, with a counter-critical perspective, the criticisms directed at the call for indigenous sociology within the framework of the four main questions mentioned above. In an earlier article (Çakı 2003), I presented some criticisms about the call for indigenous sociology. In this article, I re-examine my own criticism as well as those of other sociologists'. The purpose of doing this is to contribute more to the enrichment and development of academic debates in Turkey regarding the call for indigenous sociology.

\section{Objections/Critics to The Call for Indigenization}

Just as Western sociology was born as a reaction to socialism, the call for indigenous sociology was born as a reaction to Western sociology. Later, indigenous sociology itself faced some reactions. It is necessary to evaluate what these reactions are, how right/appropriate reactions they are, and whether they are strong enough to completely push this call out of the agenda. In this context, my priority will be to examine what kind of objections/criticisms ${ }^{2}$ come from within Turkish sociology. Where appropriate, objections from the world will also be included.

\footnotetext{
${ }^{2}$ On the occasion of the 100th Anniversary of Sociology in Turkey and before that, many articles were published on the state of Turkish sociology. However, the criticisms in these articles should not be confused with criticisms of the call for indigenous sociology.
} 
When the objections/criticisms to the call for indigenous sociology are examined in terms of Turkish sociologists, the most striking point is the general silence of sociologists who do not cross paths with the Sociology Department of Istanbul University Faculty of Letters (IUEF). In this department, those who study sociology at undergraduate or graduate level are more interested in the subject, even if they work in different institutions. In other words, almost all of those who write for or against the call for indigenous sociology are, in one way or another, affiliated with the IUEF Sociology Department.

Since they more or less reflect the general criticisms on the subject, the criticisms of three Turkish sociologists (Çakı 2003; Şan \& Şenkaloğlu 2019; Dellaloğlu 2020) will be emphasized here. Criticisms/arguments to the call for indigenous sociology will be presented by classifying them in four items within the framework of the questions asked above.

\section{Failure/Ineffectiveness Argument}

One of the important arguments of Turkish sociologists who criticize the call for indigenous sociology is that those who make this call or accept the importance and necessity of this call cannot create a satisfactory success story in producing sociological studies in line with the call's requirements. Şan \& Şenkaloğlu (2019: 51) and Dellaloğlu (2020) emphasize this point, as do Çakı (2003: 109), who published the first critical article about this call in Turkey. Çakı (2003) and Şan \& Şenkaloğlu (2019) approach this criticism, which is also underlined in international literature ${ }^{3}$, from a perspective of determining the facts. Çakı (2003: 109) argues that "even though it is a self-consistent and historically valid idea, the efforts for the indigenization of social sciences remained largely a wish and did not achieve concrete success." That is because, for him, the dependency relationship with Western sociology and the academic infrastructure in the countries where the call for indigenous sociology was made do not allow for successful/effective results for the call. Similarly, Şan \& Şenkaloğlu (2019) analyze, as will be explained in detail below, that success does not take place mainly because certain developments in the world and in Turkey make the call for indigenous sociology unnecessary.

Unlike the others, it is seen that Dellaloğlu's (2020) critique is mostly based on political and ideological motivations and on a cynical language and tries to caricature the call for indigenous sociology. According to Dellaloğlu, who published an article titled "The Sociology

\footnotetext{
${ }^{3}$ For example, according to Keim (2011: 128), calls for the indigenization of sociology have appeared to have had little discernible effects on the hierarchies of the discipline more generally, although they have opened up 'spaces for alternative voices' (see also Keim 2008; Bhambra 2013).
} 
of Indigenous Sociological Discourse" on the subject on the GazeteDuvar dated May 21, 2020, " "the discourse of 'indigenous sociology', which has been chanted continuously since the $1990 s^{4}$, has not yet produced anything worthwhile, to justify itself, at least." In other words, "it could not realize a paradigmatic transformation suitable for the prevalence of this discourse." That is because, he claims, the issue was not "scientific, academic, epistemological." In conclusion, according to Dellaloğlu, "indigenous sociology is an irritating refrain that its defenders complain about all the time and even identify themselves a little bit with this organized complaint culture. Even though users of this refrain do not like or even hate Western sociology, they still fail to create something comparable with it."

Dellaloğlu clearly appears to be unaware of the international literature on this issue, while claiming that the issue was not "scientific, academic or epistemological." In addition, it is undoubtedly clear that indigenous sociology advocates are critical of Western sociology, but it is unclear what Dellaloğlu is relying on while claiming that those advocates "even hate" it. In the aforementioned article, Dellaloğlu tries to determine the class bases of those who claim this discourse, almost without mentioning the main arguments of the indigenous sociology discourse. According to him, although the academic staff produced by the Republic until the 1980s were "generally secularized middle and upper class cadres", "after the 1980s, with the publicization of rural, tradition and religiosity, a new sociological, class base(s) began to reach the university". As a result of its inception, this discourse has gained strength; that is to say, this discourse actually has a "primarily political, sociological and class character, rather than being academic, epistemological, methodological". Therefore, according to Dellaloğlu, the discourse of "indigenization" is "a manifestation of the desire to underline that those sociologists who grew up after the 1980s are different from the first generation sociologists and their teachers." Interestingly, Dellaloğlu also argues that this new generation is "generally a more conservative, more Islamist, more right-wing generation of sociologist".

Almost none of these theses of Dellaloğlu have scientific justification, as will be explained below. Even if his arguments about the class foundations of those calling for indigenous sociology are correct - which they are not - it does not detract from the "scientific, academic, epistemological" value of this call. It is obviously a contradiction that Dellaloğlu does not look at class foundations of Western sociologists whose theories he uses as he wishes but takes the class foundations of those who call for indigenous sociology as a basis. In addition,

\footnotetext{
${ }^{4}$ In fact, it should be "since the 1980 s or even the 1970 s".
} 
in this context, Dellaloğlu puts himself in a position to accuse important sociologists such as Baykan Sezer and Korkut Tuna, the pioneers of the call for indigenous sociology in Turkey, to be somebody who entered the university environment as a result of "the countryside, tradition, and piety" taking a public appearance 5 . How does Dellaloğlu know that this call is "a manifestation of the desire to underline that those sociologists who grew up after the 1980s are different from the first generation sociologists and their teachers"? It is clear that Dellaloğlu does not contribute to the dispassionate evaluation of the controversial call with these arguments, because he speaks like an ideologue rather than a scientist. Even if it is accepted for a moment that Dellaloğlu knows what manifestation of desire those who call for indigenous sociology are making this call for, and even if it is accepted that he knows this correctly, it is still worth asking what is wrong with a scientist's "effort to differentiate himself from the ones before him." If he does not have a scholastic mindset, would not any scientist be expected to do so anyway? Besides how Dellaloğlu measures that the new generation that grew up after the 1980s and embraced this discourse is "generally a more conservative, more Islamist, more rightwing generation of sociologist", it is also worth asking what difference it would make to know this. Does he mean that we can turn a blind eye if any call comes from a conservative, Islamist, right-wing sociologist generation?

Knowing the class background of sociologists in general helps us to better understand their views and suggestions. But knowledge of class background cannot be a just and sufficient reason for us to reject or try to discredit a sociological theory or call. Whether we are the defender or the objector of the call for indigenous sociology, it is necessary to clarify why it did not have the expected effect. However, it seems that Dellaloğlu's arguments do not help us in any way to understand the reasons for this narrow/limited effect. As Bhambra (2013: 303) points out, despite the fact that feminist theory developed at the same time as the call for indigenous sociology, it created much greater interest and influence. Then, what is the best way to understand the limited impact of the call for indigenous sociology? Could it be important changes in the world conjuncture? The next argument will be directly related to this.

\section{The 'New World' and 'New Turkey' Argument}

Despite the fact that Şan gives a clear support to the call for indigenous sociology in an article dated 2007, Şan \& Şenkaloğlu (2019) in a new article dated 2019, find it inevitable to

\footnotetext{
${ }^{5}$ It is enough to look at the biographies of these people in order to understand whether the mentioned professors are "secularized middle/upper class cadres" or the representatives of "the countryside, tradition and piety". It may also be a matter of curiosity what the class basis of Dellaloğlu himself is.
} 
review the necessity of this call due to the changing conditions in the world and in Turkey: "Turkey is able to bring unique explanations both within and around the world. However, in today's world, it has become inevitable to reconsider the necessity of indigenous sociology ${ }^{6}$ in the face of rapid change in the world and the rapid change in needs and the rapid differentiation of our recurring problems together with the needs" (Şan \& Şenkaloğlu 2019: 50). Well, what kind of change has occurred in the world and in Turkey, and how did these changes affect the call for indigenous sociology?

At this point, Şan and Şenkaloğlu (2019) highlight the developments around postmodernism and globalization. According to them, "After the 1980s, in many parts of the world, with the global process arising from postmodern discourses, change began to occur even more rapidly in all areas of life. With the globalization discourse, the perception that the world is a single place has been accepted and it has been possible to say that the borders have disappeared. [...] We are now in a period in which the globalization process, which has originated from the discourses of postmodernity, has become widespread rapidly. In this period, the fact that the indigenization movement that emerged in the face of the problems arising from the Eurocentric ideology of Western sociology was presented as a solution to the postmodern changes did not matter anymore" (Şan \& Şenkaloğlu 2019: 52-53). In other words, according to Şan \& Şenkaloğlu (2019: 43), "as a result of the criticism of the Eurocentric understanding, the egocentric western understanding of sociology, which limits the science of sociology, has ceased to be a problem.” Referring to Alatas (2016: 184), Şan \& Şenkaloğlu (2019: 43) argue that "in a world where Eurocentrism has lost value, it is futile to oppose Eurocentric understanding, to seek the idea of indigenous sociology or to seek alternative sociology."

These views of Şan \& Şenkaloğlu are one of the ways to bring an explanation to the problem. However, it would be unfair to reduce the call for indigenous sociology to the level of a reaction to the Eurocentric character of Western sociology. Undoubtedly, the reaction to Eurocentrism is one of the most important starting points of the call for indigenous sociology, but it is not limited to it. First of all, the call for indigenous sociology, which accepts that the production of knowledge cannot be independent of power relations, is also a call for the reconstruction of sociology in order to challenge the relations of intellectual dependence. Have the processes of postmodernism and globalization ended the intellectual dependency and power

\footnotetext{
${ }^{6}$ According to Yelken (2014), we need to transcend the discussion of "indigenousness" and " indigenous sociology". However, Yelken argues that "we need to think in the context of Islamic Civilization, which includes the Ottoman Empire", which is a kind of call for indigenousness.
} 
relations in question so that the call for indigenous sociology is now "unnecessary"? As Çak1 (2003: 110) emphasizes, although the concept of "our interests", which is one of the key concepts of the call for indigenous sociology, continues to remain ambiguous, can we consider them to be the same with the interests of others even in the processes of postmodernism and globalization? In addition, in an environment where postmodernism celebrates pluralism with its openness and tolerance to all kinds of ideas, it is still unclear why the call for indigenous sociology should be seen as "no longer necessary", while the existence of feminist theory with a separate identity and influence is not required to be questioned.

Although the "needlessness" of the call for indigenous sociology has not been fully explained within the framework of new developments in the world, maybe it can be explained by developments in Turkey? In this context, Şan \& Şenkaloğlu (2019) offer another explanation by comparing the conditions of old/new Turkey in a way: "When we look at the new relations that Turkey has established with both Western and non-Western societies, we can better evaluate the call for indigenous sociology. Though it has provided new perspectives, it is now clear that it is no longer needed. That is because Turkey is now aware of its own identity and acts according to its interests in the face of Western sanctions in both political and social issues. Turkey is a country that never hesitates to cooperate with the West in line with its political and social interests, but never identifies its identity with the West. The facts that Turkey's relations with Western and non-Western societies have changed over time and that Europe's egocentric/monopolistic attitude has received severe criticism has made the idea of indigenization unnecessary for Turkish sociologists who want to build a better science for the future together with the experience of yesterday. If we look at the issue in terms of the necessity of indigenous sociology, we see that in the new discourse, indigenous sociology (the boundaries of which are determined according to power relations) has lost its function" (Şan \& Şenkaloğlu 2019: 54).

Although these analyzes of Şan \& Şenkaloğlu bear some truth, it cannot be said that they adequately justify the "needlessness" of the indigenous sociology project. First of all, it does not seem right to reset an academic/epistemological project with an uncertain political conjuncture. Even if we accept that Turkey's power against the West is higher than in the recent past, we have to admit that this power is quite fragile. Aside from the economic fragilities we frequently witness, it should not be forgotten that until 15 July 2016, the West managed to infiltrate and control Turkey's most important institutions through FETÖ, which looked generally quite civilian. Unfortunately, the "new Turkey's power" is not enough to ensure the 
extradition of even one of the terrorists wandering in Western countries, despite the joint extradition agreements signed.

My second point of criticism is that the fact that Turkey is "stronger" compared to the past should not be a reason to give up on indigenous sociology; on the contrary it should be considered to be a stronger chance to put it into practice. The fact that the current political power's expression of aims to be "indigenous and national" the political conjuncture is also suitable for this chance to come to life. While we do not give up on the aim of being "indigenous and national" in the field of military technology, it is worth asking why we should give up the indigenization of social sciences and why the current political power does not carry out any serious policy in this direction.

Thirdly, if we see the call for indigenous sociology as "no longer necessary" with the acceptance that "we have become a stronger and more independent country" than before, how can we explain the fact that the West produced a Eurocentric sociology during its most powerful periods (in the 19th and 20th centuries)? More importantly, isn't one of the most important reasons for the West to give up its great (Eurocentric) discourses in a time when the challenges to its economic, political and intellectual hegemony in the world (in the 21 st century) are rising, to prevent alternative discourses to itself?

As a result of these evaluations, we can say that Şan \& Şenkaloğlu's criticism of the call for indigenous sociology with reference to developments in the world and in Turkey is important and valuable but requires further examination and discussion.

The 'Incompatibility with the Disciplinary Integrity and Scientific Identity of

\section{Sociology' Argument}

All three sociologists, whose criticisms I have examined against the call for indigenous sociology, are of the opinion that this call has or may disrupt the disciplinary integrity of sociology. In particular, taking into account some of its versions, Çak1 states that "the indigenization movement has not yet achieved a harmonious and consistent integration of the criteria of 'indigenousness' and 'scientificity" that "compromise from being scientific in favor of indigenousness is common" and that "this situation leads to the loss of credibility for the

\footnotetext{
${ }^{7}$ By referring to the "national sociology" expressed by Gökalp and the "indigenous sociology" advocated by the Baykan Sezer/Korkut Tuna line, Orçan (2014: 58) argues that 'nationality' and 'indigenousness' signify different things in that one reflects the demands and preferences of the state and the other of the society. On the other hand, Çak1 (2003: 110) argues that the solution to social problems in Baykan Sezer's sociology is through the state, and that the main mission of sociology is to convince the state of the wrongdoing of Westernist politics.
} 
current movement" (Çakı 2003: 109). However, this criticism of Çakı points to the necessity of paying more attention to its scientific identity, rather than abandoning the call for indigenous sociology.

On the other hand, Şan \& Şenkaloğlu (2019) and Dellaloğlu (2020) seem to accept the inherent incompatibility of the call for indigenous sociology with the disciplinary integrity and scientific identity of sociology. According to Şan \& Şenkaloğlu (2019), "a science cannot have belonging and limitations. Our aim as sociologists is not to do Eurocentric or alternative sociology. Our aim should always be doing 'sociology' as sociologists" (Şan \& Şenkaloğlu 2019: 43). From these words, we cannot deduce that Şan \& Şenkaloğlu think there is only one way to "do 'sociology' as sociologists," but we can at least ask the following question: Don't those who call for indigenous sociology do sociology? Also, if "a science does not belong", why do Giddens and many others present sociology as the science of "modern society"? Why does science turn into a tool of domination of power, as Foucault argues?

On the subject, Dellaloğlu (2020) appeals to the community of sociologists and invites them to accept that sociology is now a science, even "the natural science of society". Based on the view that "just as an indigenous urology is impossible, so is indigenous sociology", Dellaloğlu says that we should not be offended with the fact that sociology is built or invented in the West, "like smart phones in our pockets." Because it now costs all humanity, there can be no 'indigenous sociology or foreign sociology', but 'quality sociology and poor quality sociology' or 'sociology about Turkey as more or less a theme' can be mentioned.

Especially the last sentence of Dellaloğlu ("Sociology with Turkey as more or less as a theme") shows that he has a narrow understanding of the call for indigenous sociology. Because defenders of indigenous sociology often state that, contrary to what Dellaloğlu thinks, they do not see indigenous sociology as a sociology that focuses only on the local. For example, according to Alver (2014: 33), Turkish sociology should position itself on two main axes. On the one hand, it should be able to develop a method based on society, history and original issues by developing a local perspective, and on the other hand, it should be able to establish a universal perspective by following other worlds, societies, issues and imaginations. As Çav (2019: 110) states, "indigenous sociology is not one that aims to reach a single movement, tradition, ideology, doctrine, system or approach, a limited understanding of region and geography, a world thought and mentality functioning based on rupture, or a sociology closed to outside." (see also Şan 2007: 81). 
In fact, Alatas (2006: 87) clearly explains the relation of indigenous sociology to the universal: "It should, therefore, be apparent that the projects involving indigenization of knowledge around the world seek to contribute to the universalization of the social sciences by not only acknowledging but insisting that all cultures, civilizations and historical experiences be regarded as sources of ideas.

Indigenous social scientists should contribute on an equal basis with their Western colleagues to international scholarship." Hence, according to Alatas, there is a very close relationship between indigenization and universalization; even according to him, "indigenization and universalization are one and the same thing" (Alatas 2006: 87).

There is no doubt that the comparison of " indigenous urology / indigenous sociology", which Dellaloğlu presented as a brilliant idea, and the inference that sociology is "like smart phones in our pockets", together with the metaphor of "the natural science of society", will make the defenders of indigenous sociology smile ${ }^{8}$, but it is possible to distinguish between "quality sociology and poor quality sociology". They would not object this distinction because it can also be applied to indigenous studies. However, while talking about a singular sociology or convincing ourselves that there can only be "good" and "bad" ways of doing sociology seems to solve the problem on paper, it is not so easy in practice. For example, among Turkish sociologists, does Ziya Gökalp make a more "quality" sociology, or Prince Sabahaddin? Is Şerif Mardin making a more 'quality' sociology, or Baykan Sezer? ${ }^{9}$ Who will decide on this? Despite the Eurocentric character of their sociology, did sociologists like Marx, Durkheim, and Weber do poor sociology? Should we look at Bourdieu or somebody else as an example of doing quality sociology?

Both Şan \& Şenkaloğlu (2019) and Dellaloğlu (2020) are not alone in their critique of the inherent incompatibility of the call for indigenous sociology with the disciplinary integrity and scientific identity of sociology. For example, Margaret Archer (1991), referring to the call for indigenization in the International Sociological Association's (ISA) Presidential Speech titled "Sociology for One World: Unity and Diversity" in 1991, emphasized "the irony of an

\footnotetext{
${ }^{8}$ By making a comparison between "left-wing sociologists" and "conservative, Islamist, right-wing sociologists" whom he identifies with the indigenous sociology discourse, Dellaloğlu claims that leftist sociologists contribute more to sociology because "they have more command of the basic criteria and traditions of the field." This is quite an interesting argument because he doesn't explain what kind of research he conducted to measure contributions of those opposite wings and how he reached at such a conclusion. In a sense it sounds like the generalization of "blonds are stupid."

${ }^{9}$ The western epistemic community would probably adopt Şerif Mardin as a better sociologist. Wonder why?
} 
increasingly globalized society being met by an increasingly localized sociology" and advocated the "basic unity of humanity", which requires a single sociology discipline for "one world" (cited in Adésínà 2002: 94). Archer's Sociology for One World is a global sociology whose core concepts are based on Western sociology. The only place given to other voices in this sociology is the translation of these concepts into vernacular idioms. As Adésínà argues, Archer's call for 'one humanity' is one that takes up its unity by refusing to give a voice to nonWestern (and non-dominant voices in the West) (2002: 94). For Archer, the West has little to learn from sociologists elsewhere; "just an appreciation of their confirmation of the validity of what was being argued prior to engagement and thus an ability to continue as normal with minimal disruption after engagement” (Bhambra 2014: 84). Sztompka (2011), another term president of the ISA, also, following in the footsteps of Archer's (1991) previous comments, argued that "there is, and can be, only one sociology studying many social worlds" (cited in Bhambra 2014: 105).

It is seen that there is an intersection between Archer's understanding of 'one humanity' and 'sociology for a single world', and Şan \& Şenkaloğlu's understanding of "a science cannot have belonging and limitations" and Dellaloğlu's understanding of "no indigenous or foreign sociology". These intersecting views turn into a common rejection of the call for indigenous sociology. Thus, their views imply that the call for indigenous sociology has expired. Adésínà (2002: 95) aptly argues that both the adoption and rejection of the call for indigenous sociology are problematic because they placed the arguments being made into a 'ghetto' removed from critical engagement. Particularly, Dellaloğlu's arguments, which are supposedly based on a class analysis, do not problematize this ghettoization in Turkey, but reinforce it. It will be discussed below whether the call for indigenous sociology has really come to an end or whether it has evolved into another form.

\section{Arguments about the 'Reversal of Eurocentrism' and the 'Limits of Universality'}

Çakı (2003) criticizes that many approaches adopted in the name of indigenization and to oppose Eurocentrism, paradoxically, have a reinforcing effect on Eurocentrism (2003: 109), and that at the same time, the indigenization movement, paradoxically again, can take an ethnocentric position while opposing Western Eurocentrism. According to him "indigenization in this respect potentially carries the danger of contributing to the strengthening of racism in the world" (Çak1 2003: 110). Calls for Afrocentrism, for example, move in the opposite direction of Eurocentrism (Keim 2011: 4). 
If indigenous sociology does not go beyond replacing Eurocentrism with, for example, Afrocentrism or Asiacentrism, then what meaning may it have? In this case, the epistemological problems within Eurocentrism will also be in the nature of indigenous sociology. For example, cultural essentialism may become a fundamental problem of indigenous sociology.

On the other hand, Çakı (2003) argues that the call for indigenous sociology, especially in Turkey, has weakness in meeting the requirements of being in relation, communication and interaction with the international sociological literature on the similar (and different) problems and effects created by the modernization/Westernization processes that go beyond the Turkish society.

Sociologists such as Martin Albrow and Sujata Patel, who participated in the discussions on the subject, share views supporting these criticisms of Çak1. Albrow (1990), for example, in his discussion of the emergence of indigenous sociologies, highlights two key issues that need to be addressed: First, the limits of the potential universality of knowledge produced within the framework of indigenous sociologies; and, second, the difficulties of communicating this knowledge within sociology and globally (1990: 102). Patel, too, is of the opinion that discussions of indigenous sociology have evolved over time from "creating an alternate and autonomous universal theory (as it happened in India) to a discussion and investigation of the ideas, ideologies and practices of constructing scientific knowledge of 'local' cultures and to debate the epistemological basis of this local 'science"” (Patel 2010: 9).

These views and observations of Çakı, Albow and Patel actually point to the possible paths that the call for indigenous sociology may take, rather than the necessary consequences. If the call for indigenous sociology is to be the 'science of local culture', it will be completely unnecessary, since folklore or cultural anthropology can already fulfill this mission. For this reason, it is possible to evaluate this kind of understanding of 'indigenous sociology' that have entered this path as deviating from their original purpose and mission. It is the basic expectation that the local knowledge produced or can be produced by the call for indigenous sociology overcomes the problem of relativity and contributes to universal learning. Indeed, according to Patel (2010), what makes the call for indigenous sociology meaningful and valuable is to create an 'alternative and autonomous universal theory' against Eurocentrism.

\section{Arguments on the Transformation/Future of the Call for Indigenous Sociology}

The criticisms I have examined above are generally that the call for indigenous sociology has expired its life time. Accordingly, Eurocentrism is no longer a problem; now it 
is enough to "make quality sociology", so we can give up on indigenous sociology. I have also discussed the limitations of this approach. It should be clear by now that the call for indigenous sociology is not a call that can be thrown out of the agenda immediately. But there are also various real or potential problems with this call. So, what future could the call for domestic sociology have in global sociology? In other words, what is the possibility of this call to evolve by reformulating itself and thus to preserve its existence and contribute to global sociology?

Within the framework of these questions, it is seen that new approaches aiming to neutralize the Eurocentrism critique of the call for indigenous sociology but to maintain the dependence on the main skeleton of Western sociology have emerged. At the same time it is observed that some other approaches aiming to strengthen the bond of the call for indigenous sociology with a global sociology have been developed.

It is seen that one of the approaches that have emerged to neutralize the Eurocentrism critique of the call for indigenous sociology is the approach of multiple modernities. Since the second half of the 1990s, a group of theorists, including Charles Taylor (1995) and Shmuel Eisenstadt (2000), approached modernity differently from traditional modernization theorists who regarded the differences observed in the world in terms of their relations with capitalism and modernity as archaic differences that would disappear through gradual modernization. According to the new approach, there are various ways leading to modernity. Multiple modernities perspective holds that different historical trajectories and sociocultural backgrounds also give rise to quite different forms of modernity in different parts of the world and that these modernities cannot be fully understood in terms of categories and concepts developed to make sense of Western modernity. Defenders of this perspective claim that modernity is crystallized around great human civilizations such as European, Chinese, Indian, Islamic, Latin American civilizations etc. (Patel 2010: 14).

The theory of multiple modernities, too, still maintains a strong belief that there is a European (and Western) phenomenon in the origin of modernity, but unlike the previous one, it accepts that in the process of outward spreading of modernity, various cultures and societies interact with their different traditions and create a certain multiplicity. Thus, as Bhambra (2013: 301) has put, the theory of multiple modernities accepts the structural inclusion of multiplicity within the conceptual framework of modernity as "sufficient modifications to answer the postcolonial critique of modernity as Eurocentric." However, it is difficult to accept this as a sufficient change because this theory, while talking about multiple modernities, emphasizes 
aspects such as autonomy, emancipation and reflexivity, and evaluates the European model modernity as the ideal type. On the other hand, it generally accepts other models as a pathological by emphasizing their discipline and restrictive controls (see Arnason 2000). According to Bhambra, "theorists of multiple modernities seek to disarm criticism by allowing for multiplicity at the same time as maintaining the fundamental structure of the original argument. The idea of multiple modernities can be argued to represent a kind of global multiculturalism, where a common (Eurocentered) modernity is inflected by different (other) cultures" (2013: 303). In this respect, it can be said that the approach of multiple modernities is similar to the argument of Sztompka (2011), who was the ISA president for a term, as cited above, that "there is, and can be, only one sociology studying many social worlds."

Considering the specified features and tendencies, it can be said that the approach of multiple modernities cannot actually eliminate the Eurocentrism critique directed by the call for indigenous sociology and therefore cannot replace it. For the so-called "multiple" or "alternative" modernities become mere variants of European modernity, which originally emerged from "Western civilization" and then spread to other "civilizations". In this respect, this approach reminds the essentialism of Orientalists (Go 2016: 8).

Another candidate approach to neutralize the Eurocentrism critique of the call for indigenous sociology is Ulrich Beck's (2000, 2002, 2006) global cosmopolitanism approach. Close to my point stated at the beginning of the article, "Western sociology has actually made its own 'indigenous sociology'", but in another context, Beck also emphasizes the "localism" character of Western sociology. Beck makes this emphasis as a constraint to future developments. For Beck, the problem is "how to avoid the relativism of local knowledges, including that of Western sociology, rather than how to learn from local knowledges elsewhere" (Bhambra 2013: 306).

Beck's (2000, 2006) global cosmopolitanism approach evaluates modernity and the role of sociology in the context of the first and second ages. According to Beck, who accepts that modernity is now multiple, the concepts used in the development of sociological understandings in the first age are no longer sufficient for the task of understanding modernity in the second age. Because the standard concepts of social sciences that emerged in the first age were concepts developed to understand a world consisting of nation-states. However, now that we are in the 
second age ${ }^{10}$, that is, in the age of global modernity, the concepts of the first age are no longer suitable for understanding the realities of today's world. In the new era we live in, what is needed, according to him, is a new set of categories and concepts that will emerge from the reflection of this new cosmopolitan era of modernity represented by movements towards world society (Bhambra 2013: 307). Therefore, in accordance with the requirements of this new age, Beck calls for a cosmopolitan sociology. These thoughts of Beck and Wallerstein's (2004) wellknown world systems theory appear similar to each other; both advise us to shift our provincial perspective from Western nation-states to the "world system" or "global modernity" as a whole.

It seems that Beck is not concerned with the memory of the global past, but simply with how a cosmopolitan vision of the future can have an impact on the politics of the present. However, any vision of the future cannot be shaped apart from past heritage or perceptions of the past. Despite this, Beck, as Bhambra (2013: 307) has identified, pushes aside the inequalities stemming from its historical legacies such as European colonialism, imperialism and slavery, and continues to imagine a world separate from the resolution of these inequalities.

It now becomes clear that both multiple modernities and global cosmopolitanism approaches essentially continue the earlier analytical frameworks associated with Eurocentric modern understandings. By replacing "Modern" with "global", these approaches naturalize an increasingly contentious sociological history, allowing sociologists to avoid the fundamental question between modernity and sociology. Consequently, understandings of "global sociology" appear to emerge with the collection of "new" knowledge from different places, with little consideration of the long-standing connections between the places where knowledge is constructed and produced. As Bhambra (2013: 311) argues, a global sociology that aims to transcend Eurocentrism requires both a forward-looking and a retrospective reconstruction: "global sociology would require sociology itself to be re-thought backward, in terms of how its core categories have been constituted in the context of particular historical narratives, as well as forwards in terms of the further implications of its reconstruction."

Another approach that is an extension of the call for indigenous sociology, but which is tried to be separated from it, is the call of S. H. Alatas $(2002,2006)$ for the establishment of an autonomous social science tradition. Alatas (2002) argues that this call should not be confused with the previous one and that thinking about the differences between them is not "just a

\footnotetext{
${ }^{10}$ Behbehanian \& Burawoy (2011) also call for a "third stage" of sociology with a similar but triple classification. While the "first stage" of sociology examines communities and the second stage nation-states, the third stage "examines the world in terms of global civil society (as cited in Go 2016: 7)
} 
discussion of terminology", but rather tries to eliminate the serious deficiencies in the indigenization paradigm (S. H. Alatas 2002: 155). For him, the previous indigenization movement was concerned with the realm of the "relative and particular" rather than the "general and universal", and as such it could not facilitate the development of the social sciences because its focus was on "putting existence [Western social science] into a pre-existing mold" rather than breaking existing schemas of things to create something new" (2002: 155-156).

As it can be understood from here, Alatas presents two implicit criticisms. First, the indigenization project accepts the Western social sciences wholesale and adapts it to suit local conditions. According to this criticism, indigenization has not provided any break from the dominant Western paradigm or has not attempted to create a new tradition different from this paradigm. Instead, indigenization has remained part of the imitative thinking process, which marks the failure to decolonize knowledge and is presented as just a variation of Western social science. Second, this indigenization is locked in a particularist, ethnographic framework that does not try to create universal knowledge (S. H. Alatas 2006: 11).

In order to overcome these problems, Alatas' proposal is the establishment of an autonomous but universally valued social science tradition. The general logic of this proposal can be summarized as follows: "there are regional cultures with their own specificities (civilizations); one of these cultures (Europe) established a tradition of scholarship around its particular epistemologies that became globally dominant; other regional cultures need to mine their deep heritage in order to locate local, yet autonomous-origin, equivalents (for example, Ibn Khaldun) and then develop regional traditions around these foci; once established, these regional traditions can become entangled with the European tradition (which remains both local and global) and thereby create a multicultural global sociology" (Bhambra 2014: 95).

A dispute that arises during the construction of indigenous/autonomous social sciences is what the reference source will be in this process. For Alatas, the source is the views of intellectuals (e.g. Ibn Haldun) who think in terms of local categories and concerns in the past heritages of South/non-Western societies. In contrast, for Akiwowo (1986: 67), this source is folk wisdom and concepts. Indeed, Akiwowo (1986) argues that ritual oral poetry in Yoruba, which aims to oppose Eurocentric social science and "redirect the discipline into African reality", could be the basis of a new sociology. Thus, according to Akiwowo, who introduced the idea of asuwada, or "clustering of various iwa (entities)" as the new key concept, the concept established in "the intellectual territory of a non-Western community", in contrast to bourgeois 
individualism, emphasizes the bonds of social self-sacrifice and spiritual allegiance, and therefore it is more suitable for African communities (1999: 119- 120).

However, in the calls for the construction of indigenous/autonomous social sciences, unsolved problems continue to be the subject of discussion. For example, whatever the reference sources are (whether Yoruban concepts uncovered from deep oral traditions or Ibn Khaldun's concepts of bedâvet and hadâret), can they help us grasp the global logic of capitalist domination? In other words, how can theories or concepts derived from specific local contexts speak to global social processes? If Eurocentric social theory, because of its locality, falls short for non-Western societies (which there is almost consensus that it does), wouldn't indigenous sociology suffer from the same problem? Wouldn't a mushrooming of particularism then occur?

Another problem concerns the logic of what counts as "indigenous", "Southern" or "Oriental" sociology. Burawoy's question is pertinent: "If there is a Southern sociology, what makes it Southern and sociological?" (cited by Go 2016: 12). Similarly, Çakı asks who the "we" refers to in the concepts of "our interests" and "our point of view", which are key concepts of indigenous sociology (2003: 110). For the most part, advocates of indigenous/Southern sociology remain silent in the face of these questions from Burawoy and Çak1.

Based on the discussions above, it can be concluded that the call for indigenous sociology and its derivatives have not been able to produce sufficient and satisfactory answers to some important criticisms, although they offer a wider repertoire of information to think about and deal with the social world. However, this still does not necessitate throwing the baby out with the water in the tub.

\section{CONCLUSIONS}

As a result of the examinations and evaluations made here, many important questions arise regarding the call for indigenous sociology that need further discussion. How meaningful and functional is indigenous sociology in a world where postmodern pluralism and globalization are celebrated? Is indigenous sociology still possible in such a world? Although the call for indigenous sociology has a significant amount of advocates, why can't it produce a success story that fits the call? How will this call be positioned within the integrity and scientific identity of the discipline of sociology? Is it necessary to abandon this call completely? Would it be more appropriate for us to aim for a global sociology rather than an indigenous one? I have discussed each of these questions above. Here I present a few conclusions based on this discussion. 
I. Indigenous sociology is not a utopia. We have a concrete example of indigenous sociology in front of us: Eurocentric Western sociology. By building concepts, theories and methods that center the culture, history, epistemology and hegemonic interests of Western civilization, it has succeeded in establishing an epistemological colonialism as well as a powerbased colonialism on non-Western societies. With the help of this epistemological colonialism, or in other words, intellectual hegemony, the West has succeeded in attracting non-Western societies to the global network/system it has developed in order to perpetuate its dominance. In this system, which started to function from the 16th century, Western sociology clearly served the Western dominance until the third quarter of the 20th century. From this point on, when things and balances began to change, Western sociology welcomed the postmodernist and globalist discourses due to their contribution to blocking the anti-Western alternative grand discourses. As a result of this, Western sociology applied to a provisional repentance regarding its Eurocentric character. However, this is not a sincere repentance; it is a repentance that is due to its interests.

II. As the call for indigenous sociology argues, the existing sociological concepts, theories and methods, which are the products of the interests and civilizational experiences of the West, are/may be insufficient or invalid to understand and solve the social realities and problems of non-Western societies coming from different historical and cultural backgrounds and social interests compared to the West. For this reason, the proposition that sociology in non-Western societies should be freed from the hegemony of Western sociology and restructured at both epistemological and ontological levels is based on justified grounds. However, there is a widespread belief that this has not been achieved.

III. The success/impact problem of the call for indigenous sociology is handled on the wrong ground. It is mistakenly thought as if the problems of a given country will be resolved and a stronger country will be created against the West as a result of the success of indigenous sociology. ${ }^{11}$. However, the situation is the opposite. The West has not established dominance in the world because it has been able to build a strong sociology historically, but because it has succeeded in establishing dominance in the world, it has been able to build a strong (and indigenous) sociology. This does not mean that Western sociology has not produced solutions to any of the problems of Western societies. In the face of some problems such as industrialization, urbanization, proletarianization, migration, social movements and revolutions

\footnotetext{
${ }^{11}$ Exactly due to such an understanding, Turkish intellectuals were interested in sociology from the very beginning at a time when the country was facing major problems.
} 
that emerged as the results of exploiting the world, Western sociology has tried to produce solutions without putting the capitalist system at risk; on the other hand, it has played the role of persuading non-Western societies to follow the West. But it is thanks to World domination that sociology can play these roles. Today, no one is going to come after us just because we started a strong indigenous sociology movement. The role that indigenous sociology will play varies according to circumstances. The important thing in today's conditions is to have a sociology that asks the right questions and makes the right analyzes that will enable us to know ourselves and the world well. Indigenous sociology can play other roles in parallel with the changing balance of power in international relations. It is also unfair to expect the call for indigenous sociology to succeed in restructuring sociology without restructuring the academic infrastructure ${ }^{12}$ in the country.

IV. Indigenous sociology does not have to be a closed sociology with stereotyped concepts, theories and methods. As the example of Western sociology in front of us illustrates, indigenous sociology can have a flexible and pluralistic character in itself. The important thing is that it is a sociology that is liberated from the intellectual hegemony of the West and that centers our social interests and perspectives within the framework of changing conditions. Whether the 'interest' and 'perspective' here will be based on the state or society is a separate issue (perhaps a basis reconciling the two can also be developed). In this regard, Eurocentric Western sociology can give us an idea. It cannot be said that Western sociologists living in the same period/society or in different periods/societies developed a discourse of history and sociology based on Western interests within the framework of structures similar to masonic organizations. It is more reasonable to think that Eurocentric Western sociology developed and institutionalized spontaneously on the basis of common interests, concerns and feelings. This is how the necessity of the call for indigenous sociology in non-Western societies or civilizational circles will probably emerge and develop.

V. The applicability of indigenous sociology is circumstantial; the real problem lies in its desirability because indigenous knowledge has the problem of relativity. It is still unclear how all indigenized knowledge, including the example of Western sociology, will contribute to universal learning. One of the ways to overcome this problem, as Beck suggests, is to put the past aside and accept that we are all in the same boat as of today's and future (global) worlds and to construct a "cosmopolitan sociology". Another way is to give a voice to non-Western

\footnotetext{
${ }^{12}$ It is clear that we do not mean the palliative changes that YÖK (Higher Education Institution) frequently makes.
} 
societies by preserving the dominant voice of Western sociology with the approach of "multiple modernities". However, these proposed ways are not sufficient to break the hegemony of Western social sciences. In addition to these initiatives, advocates of indigenous sociology invite this call to evolve towards the development of "autonomous" and "connected" global sociologies in order to overcome the problems of both relativity and dependency. In this case, "indigenization and universalization are one and the same thing" (Alatas 2006: 87). In this sense, indigenous sociology can "enable us not just to think sociology (and other social sciences) differently, but also to do it (and them) differently" (Bhambra 2014: 146).

VI. Today, the regions where indigenous /global sociology debates are most heated appear as Africa and Far-Asia. Sociologists of these regions, instead of ending the discussions about indigenous /global sociology, develop their terminology and epistemological foundations and continue them in the 21 st century and carry them to an international platform. However, Turkish sociologists stay away from the discussions in these international platforms, except for a few names. This distance, on the one hand, limits their capacity to contribute to those discussions; on the other hand, it restricts their opportunities to benefit from those discussions. Thus, the issue is trapped in a vicious circle in a ghettoized state.

Nevertheless, the interest shown in the call for indigenization makes it necessary to examine all its consequences calmly and carefully. The call for indigenization is an invitation to re-examine the structure of sociology/social sciences and to develop suitable strategies for their promotion in the different and challenging situations of modern times, as well as a suitable ground for making new openings and hearing new voices. On the other hand, although the call for 'indigenization' has gained considerable attention, it is far from unanimous as to its applicability and desirability. However, this does not necessitate giving up on it completely. After all, facing new questions and criticism strengthens paradigms against their opponents.

\section{REFERENCES}

Adésínà, J. (2002). Sociology and Yoruba Studies: Epistemic Intervention or Doing Sociology in the "Vernacular"?, African Sociological Review, 6(1), 91-114.

Adésínà, J. (2006). Sociology, Endogenity and the Challenge of Transformation, South Africa: Inaugural lecture in Rhodes University.

Akiwowo, A. A. (1986). Contributions to the sociology of knowledge from an African oral poetry, International Sociology, 1(4), 343-358.

Akiwowo, A. A. (1988). Universalism and indigenization in sociological theory: Introduction, International Sociology, 3(2), 155-160. 
Akiwowo, A. A. (1999). Indigenous Sociologies: Extending the Scope of the Argument, International Sociology, 14(2), 115-38.

Alatas, S. F. (2001). The Study of the Social Sciences in Developing Countries: Towards an Adequate Conceptualization of Relevance, Current Sociology, 49(2), 1-27.

Alatas, S. F. (2003). Academic Dependency and the Global Division of Labour in the Social Sciences, Current Sociology, 51(6), 599-613.

Alatas, S. H. (2006). The Autonomous, the Universal and the Future of Sociology, Current Sociology, 54(1), 7-23.

Albrow, M. (1990). Introduction, M. Albrow and E. King (Ed.), in Globalization, Knowledge and Society (3-13), London: Sage.

Alver, K. (2014). Türk Sosyolojisi: Tarzlar, İçerikler, Sınırlar, Sosyoloji Divanı (Asırlık Sosyoloji Özel Sayısı), 2(4), 25-38.

Amin, S. (2009). Eurocentrism: Modernity, Religion, and Democracy. New York: Monthly Review Press.

Archer, M. S. (1991). Presidential Address: Sociology for One world - Unity and Diversity, International Sociology, 6(2), 131-147.

Arjomand, S. A. (2000). International Sociology into the New Millennium: The Global Sociological Community and the Challenges to the Periphery, International Sociology, 15(1), 5-10.

Arnason, J. (2000). Communism and Modernity, Daedalus: Multiple Modernities, 129(1), 6190.

Baber, Z. (2003). Provincial Universalism: The Landscape of Knowledge Production in an Era of Globalization, Current Sociology, 51(6), 615-23.

Beck, U. (2000). The Cosmopolitan Perspective: Sociology of the Second Age of Modernity, British Journal of Sociology, 51(1), 79-105.

Beck, U. (2002). The Cosmopolitan Society and its Enemies, Theory Culture Society, 19(1-2), $17-44$.

Beck, U. (2006). Cosmopolitan Vision, Cambridge: Polity Press.

Behbehanian, L., Burawoy, M. (2011). “Global Sociology, Live!” ISA.e-Forum http://sjdspace.sagepub.com/wp-content/uploads/2013/09/EBul-Aug2011-

BehbehanianBurawoy.pdf

Bhambra, G. K. (2013). The Possibilities of, and for, Global Sociology: A Postcolonial Perspective, Political Power and Social Theory, (24), 295-314.

Bhambra, G. K. (2014). Connected Sociologies, London: Bloomsbury Publishing.

Burawoy, M. (2010). Facing an Unequal World, M. Burawoy, M.-K. Chang and M. F. Hsieh (Ed.), in Facing an Unequal World: Challenges for a Global Sociology (3-27), Volume One, Tapei: Academia Sinica and the International Sociological Association.

Çakı, F. (2003). Sosyolojinin Yerlileştirilmesi: Dünya'dan ve Türkiye'den Alternatif Yaklaşımlar, Tezkire, 35, 90-114.

Candela, A. M. (2015). Sociology in Times of Crisis: Chen Da, National Salvation and the Indigenization of Knowledge, Journal of World-Systems Research, 21(2), 362-386. 
Çav, E. (2019). Türkiye'de "Yerli Sosyoloji” İmkânı: Cahit Tanyol İle Şerif Mardin'in Yaklaşımlarının Karşılaştırmalı İncelemesi, Karadeniz Uluslararası Bilimsel Dergi, 43, 78-120.

Connell, R. W. (1997). Why is Classical Theory Classical?, American Journal of Sociology, 102(6), 1511-1557.

Dellaloğlu, B. F. (2020, 21 Mayıs). Yerli Sosyoloji Söyleminin Sosyolojisi. https://www.gazeteduvar.com.tr/yazarlar/2020/05/21/yerli-sosyoloji-soylemininsosyolojisi

Diawara, M. (2000). Globalization, Development Politics and Local Knowledge. International Sociology, 15(2), 365-75.

Eğribel, E. (2010). Türk Sosyolojisinin Olanakları Üzerine Yeniden Düşünmek: Türk Sosyoloji Geleneği ve Mirasımız Üzerine, E. Eğribel ve U. Özcan (Ed.), Türk Sosyologlarl ve Eserleri II - Temel Tartışmalar (Sosyoloji Yıllı̆̆ 20) içinde (3-15), İstanbul: Kitabevi Yayınları.

Eğribel, E. (2016). Türk ve Dünya Sosyoloji Tarihini Birlikte Yazmanın Gereği Üzerine: Türk Sosyolojisinin Kimliği, E. Eğribel, U. Özcan, H. B. Kaçmazoğlu ve S. Kızılçelik (Ed.), Türkiye'de Sosyoloji Üniversitede 101. Yıl (Sosyoloji Yıllı̆̆ 24) içinde (201-216), İstanbul: Doğu Kitabevi.

Eisenstadt, S. N. (2000). Multiple Modernities, Daedalus, 129(1), 1-29.

Fals-Borda, O., Mora-Osejo, L. E. (2003). Context and Diffusion of Knowledge: A Critique of Eurocentrism, Action Research, 1(1), 29-37.

Gareau, F. H. (1985). The Multinational Version of Social Science with Emphasis upon the Discipline of Sociology, Current Sociology, 33(3), 1-165.

Gareau, F. H. (1988). Another Type of Third World Dependency: The Social Sciences, International Sociology, 3(2), 171-78.

Genov, N. (1991). Internationalization of Sociology: The Unfinished Agenda, Current Sociology, 39(1), 1-20.

Giddens, A. (1990). Consequences of Modernity, Polity Press.

Go, J. (2016). Globalizing Sociology, Turning South Perspectival Realism and the Southern Standpoint, Sociologica, 2/2016, 1-41.

Hountondji, P. J. (1990). Scientific Dependence in Africa Today, Research in African Literatures, 21(3), 5-15.

Kayalı, K. (2009). Sosyoloji Yapmak, Türkiye'de Sosyoloji Yapmak ya da Türk Sosyolojisinin Yapı Taşlarını Oluşturmak, E. Eğribel ve U. Özcan (Ed.), in Türkiye'de Toplumbilimlerin Gelişimi II - Anglo-Amerikan Etkisi (Sosyoloji Yıllı̆̆ 18) (177-183), İstanbul: Kitabevi Yayınları.

Keim, W. (2011). Counter Hegemonic Currents and Internationalization of Sociology. Theoretical Reections and One Empirical Example, International Sociology, SAGE Publications, 26 (1), 123-145.

Kızılçelik, S. (2015). Yerli Sosyoloji, Ankara: Anı Yayıncılık.

Köktürk, G. V. (2011). Küresel Sosyoloji Çağrısı ve Türk Sosyolojisinin Tavır Belirleme Zorunluluğu, Türk Yurdu, 31(291), 177-182. 
Oommen, T. K. (1991). Internationalization of Sociology: A View from Developing Countries, Current Sociology, 39(1), 67-84.

Orçan, M. (2014). 21. Yüzyılda Türkiye'de Sosyolojinin Geleceği, Sosyoloji Divanı (Asırlık Sosyoloji Özel Sayıs1), 4, 53-64.

Patel, S. (2010). Sociology's 'Other': the Debates on European Universals, C. Crothers (Ed.), in Historical Developments and Theoretical Approaches in Sociology, II, Oxford: Eolss Publishers.

Rahbari, L. (2015). Peripheral Position in Social Theory Limitations of social Research and Dissertation Writing in Iran, Civitas, Porto Alegre, 15(1), 155-165.

Şan, M. K. (2007). Sosyal Bilimleri Yeniden Kurgulamak: Avrupa-Merkezci Yaklaşımların Aşılması Çabaları, Sosyoloji Dergisi, 3(15), 57-84.

Şan, M. K., Şenkaloğlu, S. (2019). Batı Sosyolojisi Karşısında Türkiye'de Yerli Sosyoloji Arayışı, Sosyal ve Kültürel Araştırmalar Dergisi, 5(9), 35-59.

Seidman, S. (1991). The End of Sociological Theory: The Postmodern Hope, Sociological Theory, 9(2), 131-46.

Sezer, B. (1985). Sosyolojinin Ana Başlıkları, İstanbul: İstanbul Üniversitesi Yayınları.

Sezer, B. (1988). Türk Sosyolojisinin Ana Sorunlarl, İstanbul: Sümer Kitabevi Yayınları.

Sezer, B. (1993). Sosyolojide Yöntem Tartışmaları, İstanbul: Sümer Kitabevi Yayınları.

Sinha, V. (2000). Moving Beyond Critique: Practicing the Social Sciences in the Context of Globalization, Postmodernity and Post-coloniality, South East Asian Journal of Social Science, 28(1), 67-104

Taylor, C. (1995). Two Theories of Modernity, The Hastings Center Report, 25 (2), 24-33.

Wallerstein, I. (1997). Eurocentrism and Its Avatars: The Dilemmas of Social Science, New Left Review, 226(6), 93-107.

Wallerstein, I. (2004). World-Systems Analysis: An Introduction, Durham: Duke University Press.

Wallerstein, I. (Eds.) (1996). Open the Social Sciences: Report of the Gulbenkian Commission on the Restructuring of the Social Sciences, Palo Alto: Stanford University Press.

Xypolia, I. (2016). Eurocentrism and Orientalism, The Encyclopedia of Postcolonial Studies. Ray, Sangeeta, Henry Schwarz, José Luis Villacañas Berlanga, Alberto Moreiras and April Shemak (Eds.). Blackwell Publishing, 2016. Blackwell Reference Online. http://www.literatureencyclopedia.com/subscriber/tocnode.html?id=g97814443334982_c hunk_g97814443349829_ss1-9

Yelken, R. (2014). Kurtarıcı ve Kurucu Bir Bilim Olarak Sosyoloji, Sosyoloji Divanı (Asırlık Sosyoloji Özel Sayıs1), 4, 39-51. 